\title{
Analitik hiyerarşi prosesi (AHP) yöntemi ile çalışan performansının değerlendirilmesi
}

\author{
Evaluation of employee performance by the analytical hierarchy process (AHP) \\ method
}

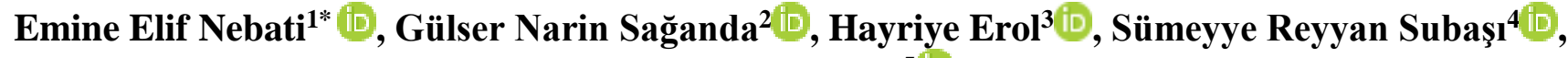 Tuğçe Esma Göz 5 (iD}

1,2,3,4,5 İstanbul Sabahattin Zaim Üniversitesi, Endüstri Mühendisliği Bölümü, 34303, İstanbul Türkiye

\begin{abstract}
Özet
Performans değerlendirme, nitel ve nicel kriterleri bir arada değerlendirebilen, işletmelerin daha etkin ve verimli karar vermesine katkı sağlayan önemli bir süreçtir. Aynı zamanda, işletmelerin rekabette güçlü kalabilmeleri açısından önem arz etmekle birlikte hedeflerine ulaşma doğrultusunda çalışanların değerlendirilmesi ve performanslarını artıracak çalışmalarda bulunmasına yardımcı olmaktadır. Bu çalışmada amacımız, İstanbul ilinde toplu ulaşım sisteminde önemli yere sahip olan bir kurumdaki, Insan Kaynakları departmanına bağlı olan Strateji İzleme birimi ve Eğitim Müdürlügüu biriminde ortak olarak belirlenen 3 görevli memurun performanslarını değerlendirmek ve gösterdikleri performansa neden olan kriterleri belirlemektir. Çalışmamızda Çok Kriterli Karar Verme yöntemlerinden AHP yöntemi kullanılmıştır. Belirlenen kriterler ve analiz ile basit, anlaşılır bir yol göstererek, uygulamalı bir yazılım programı kullanılması ile birlikte bu alanda çalışmalara bir yol gösterici niteliğindedir.
\end{abstract}

Anahtar kelimeler: Performans değerlendirme, Personel seçimi, Çok kriterli karar verme yöntemleri, AHP

\section{Giriş}

İşletmeler çalışan performansının değerlendirilmesinde daha etkin ve verimli karar verme süreçleri geliştirmesinde ve rekabette güçlü kalabilmeleri açısından önemi ile birlikte hedeflerine ulaşmak için çalışanların değerlendirilmesi ve performanslarının artırılmasına yönelik çalışmalar yapmaktadırlar. Çalışan performansının değerlendirilmesinde birçok nicel ve nitel faktör olduğu için bu çalışmada Çok Kriterli Karar Verme (ÇKKV) yöntemlerinden performans değerlendirme yöntemleri içerisinde birçok kurumda tercih edilen Analitik Hiyerarşi Prosesi (AHP) yöntemi kullanılmıştır. Kriterler ve alternatifler belirlenerek hiyerarşik yapı oluşmuştur. Çalışmada, İstanbul ilinde toplu ulaşım sisteminde önemli yere sahip olan bir kurumdaki, Insan Kaynakları departmanına bağlı olan Strateji İzleme ve Eğitim

\begin{abstract}
Performance evaluation is an important process that can evaluate qualitative and quantitative criteria together and contribute to more effective and efficient decision-making of enterprises. At the same time, although it is important for businesses to remain strong in competition, it helps employees to evaluate and increase their performance in order to achieve their goals. Our aim in this study is to evaluate the performances of 3 civil servants who are determined jointly by the Strategy Monitoring Unit and Training Directorate, which are affiliated to the Human Resources department in an institution that has an important place in the public transportation system in Istanbul, and to determine the criteria that cause their performance. AHP method, one of the Multi Criteria Decision Making methods, was used in our study. It is a guide to the studies in this field by showing a simple, understandable way with the determined criteria and analysis, using an applied software program.
\end{abstract}

Keywords: Performance management, Personnel selection, Multi-Criteria decision making, Analytical hierarchy process

Müdürlüğü birimleri için, çalışan performansını etkileyen 5 ana kriter ve her bir ana kritere ait 3'er alt kriterle birlikte 15 alt kriter olmak üzere toplamda 20 kriter ve alternatifler olarak da her iki birim için ortak olarak belirlenen 3 görevli memur belirlenmiştir.

Çalışan performansını değerlendirirken kriterlerin ne derece öneme sahip olduğunu ve alternatif 3 çalışanın performansının kriterler açısından değerlendirmek için iki birimde yer alan 6 kişiye yapılan anketlerden elde edilen değerler, çok kriterli karar verme yöntemine dayalı olarak çalışan bir karar verme yazılımı olan Superdecision programına aktarılmıştır. Yapılan çalışmayla birlikte, ortak olarak belirlenen bu 3 çalışanın mevcut durumlarının değerlendirilmesi ve bu değerlendirmeler sonucu göstermiş oldukları performansa sebebiyet veren kriterlerin önem

\footnotetext{
* Sorumlu yazar / Corresponding author, e-posta / e-mail: emine.nebati@izu.edu.tr (E. E. Nebati)

Geliş / Recieved: 04.09.2020 Kabul / Accepted: 09.04.2021 Yayımlanma / Published: 27.07.2021

doi: 10.28948/ngmuh.790551
} 
ağırlıklarının belirlenmesinden sonra çalışanlar için iyileştirici çözüm önerilerinin sunulması hedeflenmektedir

\section{Literatür özet}

Kamu sektöründe ve çeşitli sektörlerde Performans Ölçümü çalışmaları bulunmaktadır. Ulusal ve uluslararası yazında, AHP yöntemi ile ilgili birçok çalışma incelenmiş ve bu bölümde söz konusu literatür çalışmasının bir özetine yer verilmiștir.

Yaralığlu, 2001 yılında tahminleme ve karar verme amaciyla kullanılan AHP tekniğini, performans değerlendirme amacıyla yeniden gözden geçirmiş ve model bir örnek üzerine çalışmıştır [1].

Eraslan ve ark. 2005 yılında insan kaynakları uygulamalarından olan performans değerlendirme sistemine katkıda bulunmak amacıyla değerlendirme yöntemlerinde değisşikliğe gitmek için AHP yöntemini önermiștir [2].

Güney ve ark. 2010 y1lında insan performans 1 değerlendirmede yapılan hataları aza indirgemek amacıyla AHP kullanımını önermiştir. Büyük organizasyonlarda performans değerlendirme așamalarında bazı zamanlar olumsuzluklar yaşanabilmekte bu olumsuzlukları en aza indirgeme amacıyla AHP kullanımı önerilmiştir [3].

Akkaya, 2010 yılında hazırladığı çalışmada personel seçimi aşamasında AHP kullanımı hakkında bilgi vermiștir. Personel seçiminde, karar vericilerin öznel yargılarını en aza indirmek amacıyla karşılaştırmalı matrisler oluşturmayı ve seçeneklerin ağırlıklarını belirlemeyi hedeflemiştir [4].

Uçkun ve ark. 2011 yılında ülkemizde bulunan kamu ve özel bankaların finansal performanslarını gri ilişki analizi ile inceleyerek finansal oranları gruplar içinde sıralamıştır [5].

Kir ve ark. 2012 yılında 360 derece performans değerlendirme sistemini AHP tekniği ile birleștirerek bir performans değerlendirme sistemi oluşturmuş ve bunu özel bir dershanede öğretmenler üzerinde uygulamıştır [6].

Çelikdin ve ark. 2013 yllında performans ölçütlerini öncelendirmek amaciyla bir işletmede orta ve üst kademe yöneticiler üzerinde likert ölçeği kullanılan bir soru formu vasitasıyla Balanced Scorecard yöntemini AHP ile önceliklendirerek kriterleri değerlendirmişlerdir [7].

Özgür ve ark. 2014 yılında Ankara'da faaliyet gösteren 26 kamu hastanesinin göreceli etkinliklerini ölçerek etkin olup olmama konularını araştırmışlardır ve yöntem olarak VZA ve AHP'den faydalanmışlardır. 26 hastanenin değerlendirildiği bu çalışmada, hastanelerin sağlık hizmeti ortaya çıkarmak amacıyla kullandığ 4 girdi ile ürettiği 5 çıktı belirlemiş ve bunlarla iki farklı VZA modeli ile çalışılmıştır [8].

Karaatlı ve ark. 2014 yılında hazırladıkları bir başka çalışmalarında ise ülkemizde 2012 -2013 sezonu Süper Lig'de futbolcuların performanslarını değerlendirmiştir. Bunu yaparken ÇKKV yöntemlerinden AHP ile kriterlerin ağırlıklarını belirlemiş ve elde edilen ağırlıkları önce TOPSIS ve daha sonra VIKOR yönteminde kullanarak futbolcuların performansları değerlendirilmiştir [9].

Özyörük ve ark. 2014 yılında üç farklı lojistik firması performanslarını değerlendirmeleri için dengelenmiş skor kart yöntemi ve AHP'den faydalanılmıştır. Hazırlanan çalışma ile hem şirketlerin kendi bünyesinde performans ölçümü yapılabilmesi hem de şirketler arası karşıllaştırma hedeflenmiştir [10].

Karaatl 2015 yllinda savunma sanayinde bulunan bir kurum için ÇKKV yöntemlerinden AHP ve COPRAS yöntemlerini karşılaştırmalı olarak uygulamış ve yıllık performanslarını hesaplamışlardır. 2008 ve 2012 yıllarına ait veriler arasından; satış miktarı, üretim miktarı ve stok miktarı gibi verileri değerlendirme kriteri olarak belirlemiştir. Çalışma sonunda ise şirketin en iyi performansa 2012 yılında ulaştığı görülmüştür [11].

Uludağ ve ark. 2016 yılında 4 farklı cep telefonu markasının tercih edilme sebeplerini araştırmak amacıyla ÇKKV yöntemlerine başvurmuş ve hizmet kalitelerini karşılaş̧ırırken AHP'ye ek olarak TOPSIS ve VIKOR'dan faydalanılmıştır. Birçok yöntemin bir arada kullanıldığı bu çalışmada amaç Bulanık AHP yönteminin AHP yöntemine oranla nispeten çözüm sürecini kolaylaştırdığını gösterebilmektir [12].

Çalışkan ve ark. 2016 yılında bankacıllk sektöründe kaynakların kullanımı hakkında bir çalışma gerçekleştirmişlerdir. AHP ve PROMETHEE yöntemlerinden faydalanarak 2010- 2014 yıllarına ait finansal performanslarını kıyaslamışlardır. 2 uygulamadan oluşan çalışmanın ilk kısmında kriterlerin ağırlıkları eşit kabul edilmiş ve ikinci uygulamada ise AHP yöntemi ile bulunmuş ve bankaların performansı PROMETHEE yöntemi ile değerlendirilmiștir [13].

Deveci ve ark. 2016 yilında İETT ile toplu taşıma ücretlerinin belirlenmesi ve kullanıc1 memnuniyetinin sağlanması için AHP yöntemi ile optimum transit ücreti analiz etmeyi amaçlamıştır [14].

Kaynarca ve ark. 2017 yılında İETT'nin hizmet verdiği temas noktalarında hizmet kalitesini ölçmek ve müşteri memnuniyetini denetlemek amaciyla AHP yönteminden faydalanmıştır. 2012 yılında İETT tarafından oluşturulan Hizmet Kalitesi Ölçüm Modeli müşteriyi sekiz temas noktasını inceler. AHP bu temas noktalarındaki ana kriterlerin ve alt kriterlerin ağırlığını belirler [15].

Aydın ve ark. 2017 yılında savunma sanayiinde AHP ve TOPSIS ile önemli bir parça olan gövde parçası alımında en iyi tedarikçi seçimi yapmış̧ır. [16]

Gümüş ve ark. 2018 y1lında AHP ile Coğrafi Bilgi Sistemlerinden faydalanıp Niğde'de en uygun AVM yerinin belirlenmesi için çalışma yapmışlardır. [17]

Kuşakcı ve ark. 2018 yılında personel seçiminin objektif bir şekilde yapılması için bulanı MULTIMOORA yöntemini kullanmışlardır. Havacılık sektörünün önde gelen bir firmasında, çeşitli departmanlar için çalışanlarda aranılan yetkinliklerin dikkate alınmasıyla birlikte çalışan seçimi çalışması yapılmıştır. [18]

Literatür çalışmalarının tamamı incelendiğinde CKKKV yöntemlerinden AHP yönteminin en yaygın kullanıma sahip yöntemlerden biri olduğu görülmektedir. Bununla birlikte performans ölçümünde öznelliği azaltmak için kimi zaman AHP yöntemine başvurulduğu gözlemlenmektedir. Bu çalışmanın özelliği ise uygulamanın yapılacağı kurumda yapılan performans ölçümlerinde ilk defa AHP yönteminden faydalanılmış olmasıdır. 


\section{Performans analizi}

Organizasyonlar günümüzde önemli yerlere gelebilmek ve devamlılıklarını sürdürebilmek için doğru bir şekilde yönetilmeleri gerekir. Organizasyonların büyük rekabet oluşları içerisinde olmalarını sürdürebilmeleri çalışanlarının performanslarıyla ilişkilidir. Buradan performans kavramının tanımından yola çıkarak, performans başarının göstergesi, bir eylem için gösterilen uğraş olarak tanımlanmaktadır. Şartların belirlenmesiyle bir görevin yapılma seviyesi veya çalışanın işe karşı göstermiş olduğu davranış biçimine performans denir [19].

Performans belirlenen amaca ulaşmanın seviyesidir. Performans seviyesini belirleyebilmede yapılan çalışmanın sonucunun değerlendirilmesine ihtiyaç duyulmaktadır. Performans değerlendirme, bir şirketin insan kaynakları departmanının en gerekli görevleri arasında yer alır. Performans değerlendirme, yönetici tarafindan önceden belirlenmiş olan standartlarla kıyaslama ve ölçme gibi yöntemlerle çalışanların işindeki performansının değerlendirilmesi sürecidir [19]

Performans değerlendirmede, teknolojide, piyasa ve yönetimlerdeki değişimlerle birlikte performans ölçümünde kullanılan metotlarda değişime uğramıştır. Günümüzde bireysel performansın değerlendirilmesinden kurumsal performansın değerlendirilmesine geçerken çeşitli performans değerlendirme metotları bulunmaktadır. Belirlenen hedeflere göre şirketler bu metotlardan birini veya birkaçını birlikte kullanmaktadırlar. Performans değerlendirme yöntemlerinden bazıları: [19]

- Kurumsal Performans Karnesi

- Kişiler Arası Karşılaştırmalara Dayalı Yaklaşım

- İkili Karşılaştırma Yöntemi

- Bireysel Performans Standartlarına Dayalı Yaklaşım

- Geleneksel Değerlendirme Skalaları

- 360 Derece Performans Değerlendirme Yöntemi

\section{Yöntem}

Analitik Hiyerarşi Prosesi, Çok Kriterli Karar Verme Problemlerinde çokça rastlanan karar verme yöntemlerden biri olarak yaygın bir kullanıma sahiptir. Çok sayıda alternatif içerisinden seçim yapılmasında faydalanılan ve birçok karar vericinin süreç içerisinde yer alabildiği nitel ve nicel kriterlerin bir bütün olarak hiyerarşik bir yapı üzerinden işlenmesi ile hedefe varabilme yeteneğine sahip karar verme yöntemidir [20].

AHP uygulamalarında ilk adım karar vericinin amacı doğrultusunda bir karar problemi belirlemesidir. $\mathrm{Bu}$ probleme ait ana kriterler, alt kriterler ve karar alternatifleri belirlenerek hiyerarşik bir yapı oluşturulmaktadır. Öğeler içerisinde ikili karşılaştırmalar yapılarak karşıllaştırma matrisleri elde edilir bu karşılaştırma matrisleri iki faktörün kıyaslanması demektir ve karar vericinin kişisel görüşüne bağlıdır. Daha sonra her bir kriterin önem dereceleri tespit edilmektedir. Uygulamanın son aşamasında ise tüm kriterler değerlendirilir ve en uygun karar alternatifi tespit edilmiş olur [20].

\subsection{AHP uygulama adımlart}

Aşama 1: Modelin Oluşturulması:

AHP yöntemiyle karar verme sürecinde ilk olarak tüm nicel ve nitel faktörler anket çalışmalarıyla veya ilgili konuda uzman kişilerin görüşlerine başvurularak belirlenmektedir. Daha sonra elde edilen veriler ile amaç, kriterler, alt kriterler ve son olarak alternatifler belirlenerek hiyerarşik bir yapı oluşturulmaktadır.

Aşama 2: İkili Kıyaslama Matrisinin Oluşturulması:

Hiyerarşik yapı hazırlandıktan sonra Tablo 1'deki ikili karşılaştırmalar ölçeği kullanılarak bilgiler toplanmakta ve ikili karşılaştırmalar matrisi elde edilmektedir.

Tablo 1. İkili kıyaslamalarda kullanılan önem dereceleri tablosu [21]

\begin{tabular}{|c|c|c|}
\hline Derecesi & $\begin{array}{c}\text { Değer } \\
\text { Tanımları } \\
\end{array}$ & Açıklama \\
\hline 1 & Eşit Önemli & Her iki faaliyet amaca eşit katkıda bulunur. \\
\hline 3 & $\begin{array}{l}\text { Orta Önemli } \\
\text { (Az Üstünlük) }\end{array}$ & $\begin{array}{l}\text { Tecrübe ve değerlendirmeler sonucunda bir } \\
\text { faaliyet diğerine göre biraz daha tercih } \\
\text { edilir. }\end{array}$ \\
\hline 5 & $\begin{array}{l}\text { Güçlü } \\
\text { Önemde } \\
\text { (Fazla } \\
\text { Üstünlük) }\end{array}$ & $\begin{array}{l}\text { Tecrübe ve değerlendirmeler sonucun } \\
\text { diğerine göre çok daha tercih edilir. }\end{array}$ \\
\hline 6 & $\begin{array}{l}\text { Çok Güçlü } \\
\text { Önemde (Çok } \\
\text { Üstünlük) }\end{array}$ & $\begin{array}{l}\text { Bir faaliyet diğerine göre çok güçlü şekilde } \\
\text { tercih edilir. }\end{array}$ \\
\hline 9 & $\begin{array}{l}\text { Son Derece } \\
\text { Önemli } \\
\text { (Kesin } \\
\text { Üstünlük) }\end{array}$ & $\begin{array}{l}\text { Bir faaliyet diğerine göre mümkün olan en } \\
\text { yüksek derecede tercih edilir. }\end{array}$ \\
\hline $2,4,6,8$ & $\begin{array}{l}\text { Ara Değerler } \\
\text { (Uzlaşma } \\
\text { Değerleri) }\end{array}$ & $\begin{array}{l}\text { Bir değerlendirmeyi yapmakta sözler } \\
\text { yetersiz kalıyorsa, sayısal değerlerin } \\
\text { ortasındaki bir değer verilir. }\end{array}$ \\
\hline
\end{tabular}

Aşama 3: Kriterlerin Ağırlıkları ve Alternatiflerin Puanlarının Belirlenmesi:

İkili karşılaştırma matrislerinden faydalanarak her karar alternatifinin ağırlığı hesaplanmaktadır. Bu doğrultuda, ikili karşılaştırma matrisindeki her bir sütun değeri, bulunduğu sütun toplamına bölünerek matris normalleştirilmektedir. Normalleştirilmiş matristeki her sütunun toplam değeri 1 olmaktadır. Son olarak satırda yer alan değerlerin ortalamaları bulunarak öz vektörler elde edilmektedir.

Aşama 4: Tutarlılık Oranının Hesaplanması:

Tutarlılık oranını (CI) hesaplamak için aşağıdaki formüller kullanılabilmektedir.

Tutarlılık İndeksi (Consistency Index - CI)

$$
\begin{aligned}
& =(\lambda \max -\mathrm{n}) /(\mathrm{n}-1) y \\
& =m x+n
\end{aligned}
$$


Formülde CI, Tutarlılık İndeksini, $\lambda$ max matristeki en büyük öz değeri, $\mathrm{n}$ ise her bir matrisin eleman sayısını göstermektedir.

Tutarlılık oranı (CR) ise tutarlılık indeksinin aynı boyuttaki matrise karşılık gelen rastgele indekse (RI) oranlanmasıyla elde edilir;

\section{$\mathrm{CR}=\mathrm{CI} / \mathrm{RI}$}

Tablo 2. Rassal indeks serisi [22]

\begin{tabular}{cccccccccccccccc}
$\underline{\underline{n}}$ & 1 & 2 & 3 & 4 & 5 & 6 & 7 & 8 & 9 & 10 & 11 & 12 & 13 & 14 & 15 \\
\hline RI & 0 & 0 & 0,58 & 0,9 & 1,12 & 1,24 & 1,32 & 1,41 & 1,45 & 1,49 & 1,51 & 1,48 & 1,56 & 1,57 & 1,59
\end{tabular}

Tutarlılık oranı 0.10 'den küçük ise matrisin tutarlı yani karar vericilerin yargılarının tutarlı olduğu kabul edilir. [23]

\section{Uygulama}

Yapılan performans değerlendirme çalışması çoklu karar verme problemi olduğu için çok kriterli karar verme yöntemlerinden AHP yöntemi tercih edilmiştir. Çalışan performansının değerlendirilmesi için 5 ana kriter ve 15 alt kriterin tanımlanmasıyla birlikte toplamda 20 kriter belirlenmiştir. Kriterler için kurumun çalışanlar için belirlenmiş olan yetkinlikler de göz önünde bulundurularak kriterler oluşturulmuştur. Belirlenen ana ve alt kriterlerden sonra Strateji İzleme birimi ve Eğitim Müdürlüğü biriminde görevli 3 çalışan alternatif olarak belirlenmiştir. Yapılan değerlendirmeler öncesinde iki birim içinde kriterlerin ve alt kriterlerin önem derecesini belirlemek adına her iki birimden 6 kişiye uygulanmıştır. Yapılan anketlerde, ana ve alt kriterlerin değerlendirilmesi sonucunda, geometrik ortalamalar alınmış ve tek bir sonuç Super Decision programına girilerek veriler elde edilmiştir.

1. Amaç Belirleme: Ele alınan amaç, kurumun Strateji İzleme ve Eğitim Müdürlüğü birimlerinde çalışanların performansına etki eden faktörleri belirlemek ve mevcut alternatif olarak belirlenen 3 çalışan arasından en iyi performansı göstereni belirlemektir.

2 Ana ve Alt Kriterlerin Belirlenmesi: Çalışan performansının değerlendirilmesinde ana ve alt kriterlerin araştırırken birimlerden alınan bilgilerle ve ilgili literatür araştırmalarından faydalanılarak ana ve alt kriterler belirlenmiştir.

3. Alternatiflerin Belirlenmesi: Değerlendirilecek alternatifler, Strateji İzleme birimi ve Eğitim Müdürlüğü’nün ortak olarak belirlediği 3 çalışandır.

4. Hiyerarşik Yapının Oluşumu: Belirlemiş olduğumuz 5 ana kriter ve 15 alt kriter ile birlikte toplamda 20 kriter belirlenmiştir. Oluşan hiyerarşik yapı Şekil 2'dedir.

5. Anketlerin Yapılması: Anket yapılmasındaki amaç, her bir ana ve alt kriterin ikili kıyaslamalarını yapmak ve önem derecelerini belirlemektir. Anketler Strateji İzleme ve

Eğitim Müdürlüğü'nde yer alan müdür, şef ve bir çalışan olmak üzere 6 kişiye sunulmuştur.

6. Anket Cevaplarının Geometrik Ortalamalarının Alınması: Yapılan anketler sonucu, iki birimde de her bir ikili kıyaslama için müdür, şef ve çalışan verdiği cevapların geometrik ortalaması alınmıştır.
7. Geometrik Ortalamaların Superdecision Adlı Programa Girilmesi: Anketlerde verilen cevaplar 1-9 aras1 puanlama olarak, AHP metodunda yer alan kriter önem dereceleridir ve her bir kriter için tüm uzmanların verdiği puanların, geometrik ortalamaları alınarak, Superdecision adlı programda girilmiştir.

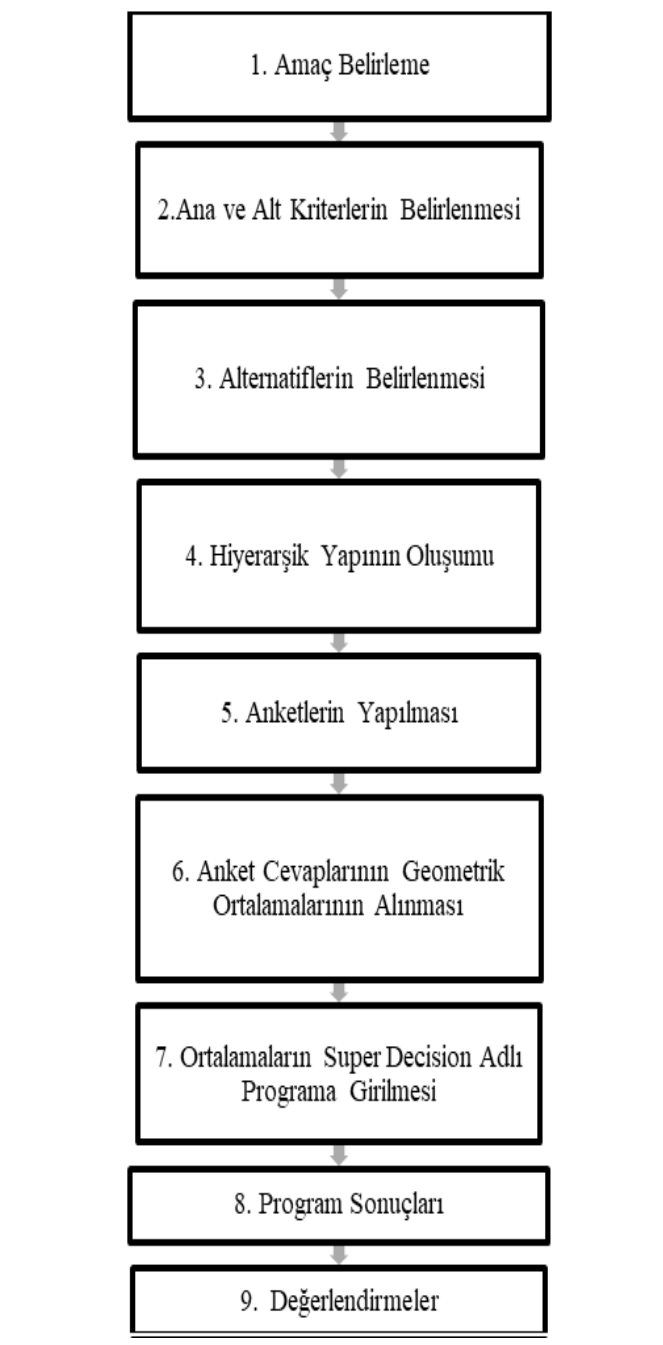

Şekil 1. Performans değerlendirmesinde izlenen adımlar

8. Program Sonuçları: Ortalamaların programa girilmesiyle birlikte her bir kriter için tutarlılık oranına bakılır. Tutarlılık oranı 0.1 'den küçük olmalıdır.

9. Değerlendirme: Çıkan sonuçlara göre hangi ana kriterin, alt kriterin en önemli kriter olduğu, hangi alternatifin en iyi performans gösterdiği belirlenmektedir.

\subsection{Seçim kriterlerinin belirlenmesi}

Seçim kriterlerinin belirlenmesi için, kurumun daha önceden personeller için yapmış olduğu performans değerlendirme çalışmalarından faydalanılarak, çalışanlarının sahip olması gerekli temel yetkinliklerin neler olduğuna dair bazı ön bilgiler elde edilmiştir. Temel yetkinliklerden bazıları aşağıda belirtilmiştir:

- Stratejik Bakış Açısı

- Müşteri Odaklılık 
- Mesleki Uzmanlık

- Takım Ruhu ve Dayanışma

- Analitik Düşünme

Yukarıda belirtilen bazı temel yetkinlikler hakkında araştırmalar yapılmıştır. Çalışan performansını değerlendirirken ne gibi faktörlerin, yetkinliklerin ve etkenlerin yardımcı olacağına dair araştırmalar dışında beyin firtınası eşliğinde çalışmamız için seçim kriterleri belirlenmiştir. Belirlenen kriterler tanımlarıyla birlikte yer almaktadır (Tablo 3)

Tablo 3. Belirlenen ana kriterler, alt kriterleri ve tanımları

Ana
Güvenilirlik
Dürüst ve Samimi Olabilme

Kriterler

Verilen görevleri yerine getirirken

iş ahlak ve ilkelerine uygun hareket edilmesi.

Doğruların ifade edilip gerçekçi davranıș sergilenmesi.

Bir görev yerine getirirken bulunulan bölümün her detayının görülüp, incelenmesi, iş ve iş ile ilgili bilgilerin sürekli takip edilerek kaynakların ve zamanın etkili kullanılabilmesi için

Dikkatli ve Hatasız Çalıșabilme Etik Kurallara Uyma

Misyon ve vizyona uygun davranılması.

Problemin önceliklendirilerek ve neden-sonuç ilişkisi kurularak

Analitik Düşünme

Neden-Sonuç İlişkisi Kurabilme

Problemleri Net Yorumlayabilme yorumlanmasi.

Olaylarda sonuçların bağlantılı olduğu sebeplerin bulunması.

Karşılașılan sorunların kısa ve öz yorumlanması.

Yapılacak işlerin sıralamasının yapılarak öne alınacak işlerin seçilmesi.

Önceliklendirme Yapabilme

Etkili İletişim

Uygun Ses Tonu ve Vücut Dili

Empati Kurabilme

Özgüven

Sonuç Odaklılık

İş Bitiricilik

İnisiyatif Alma

Takım Ruhu ve Dayanışma

Yardımseverlik

Sorumluluk Sahibi Olması

Uyumluluk

\subsection{Hiyerarş̧ik yapının oluşturulması}

Çalışmada 5 ana kriter, 15 alt kriter ve 3 alternatifin belirlenmesiyle oluşan hiyerarşik yapı Şekil 2'de yer almaktadır.

\section{3 İkili karşılaștırmaların yapılması}

Kriterlerin çalışan performansında etkisini gözlemlemek için kurumun Strateji İzleme birimi ve Eğitim birimine ait müdür, şef ve bir adet çalışan olmak üzere iki birim için toplam altı personele kriterleri ikili olarak kıyaslamak için anket uygulanmıştır. Yapılan bu anketlerden sonra bu iki birimin de ortak olarak seçtiği 3 çalışan alternatif olarak bu kriterler bazında değerlendirmiştir.

Çalışmada yer alan anket kısmında amacımız her bir ana ve alt kriterin ikili kıyaslamaların yapmak ve önem derecelerini belirlemektir. Anketlerde yer alan 1-9 aras değerlendirme AHP yönteminde yer alan kriter önem dereceleridir. İkili kıyaslamanın yapılması sırasında hangi kriterin çalışan performansında daha önemli olduğu ve Saaty'nin önem skalası kullanılarak seçilmiștir (Tablo 1). Yapılan değerlendirmeler sonrasında elde edilen değerlerin geometrik ortalaması alınır ve Superdecision adlı programda değerler girilir (Şekil 4). İkinci adımda, "Inconsistency" yani tutarlılık oranın verildiği kısma bakılır. Tutarlılık oranın 0.1 'den küçük olması gerekmektedir. Çalışmamızda her biri için tutarlılık oranları 0.1 'den küçük çıkmıştır ve tutarlıdır. Karşılaştırmaların tutarlı çıkmasından sonra kriterlerin öncelik değerleri elde edilmiştir.

\subsection{Strateji izleme birimi sonuçları}

Strateji İzleme birimi için kriter öncelik ağırlıklarını değerlendirdiğimizde (Tablo 4 ve 5), ana kriterler için yapılan değerlendirmede (güvenilirlik, analitik düşünme, etkili iletişim, sonuç odaklılık, takım ruhu ve dayanışma) kendi aralarında eşit önem derecesine (\% 6.66) sahiptirler. Alt kriterler için bakıldığı zaman \%4.6 ile "empati kurabilme" en önemli alt kriter olup, \%0.41 ile "etik kurallara uyma" ise en az önemli alt kriter olarak görülmektedir.

Tablo 4. Strateji İzleme birimine ait ana kriterlerin anket sonuçları

\begin{tabular}{cc}
\hline Ana Kriter Adları & Öncelik Ağırlıkları \\
\hline Analitik Düşünme & 0.066667 \\
Etkili İletişim & 0.066667 \\
Güvenilirlik & 0.066667 \\
Sonuç Odaklılık & 0.066667 \\
Takım Ruhu ve Dayanışma & 0.066667
\end{tabular}

Tablo 6'da yer alan alternatifler için yapılan değerlendirmede "Çalışan 3" (\%18.15) en iyi performansa sahip olarak çıkmıştır. Bunun sebebi "Empati kurabilme" alt kriterine oldukça fazla sahip olmasıdır. "Çalışan 2" (\%6.84) en kötü performansa sahip alternatif olarak çıkmıştır. Bunun sebebi ise "Etik kurallara uyma" kriterine az seviyede sahip olmasidır. 


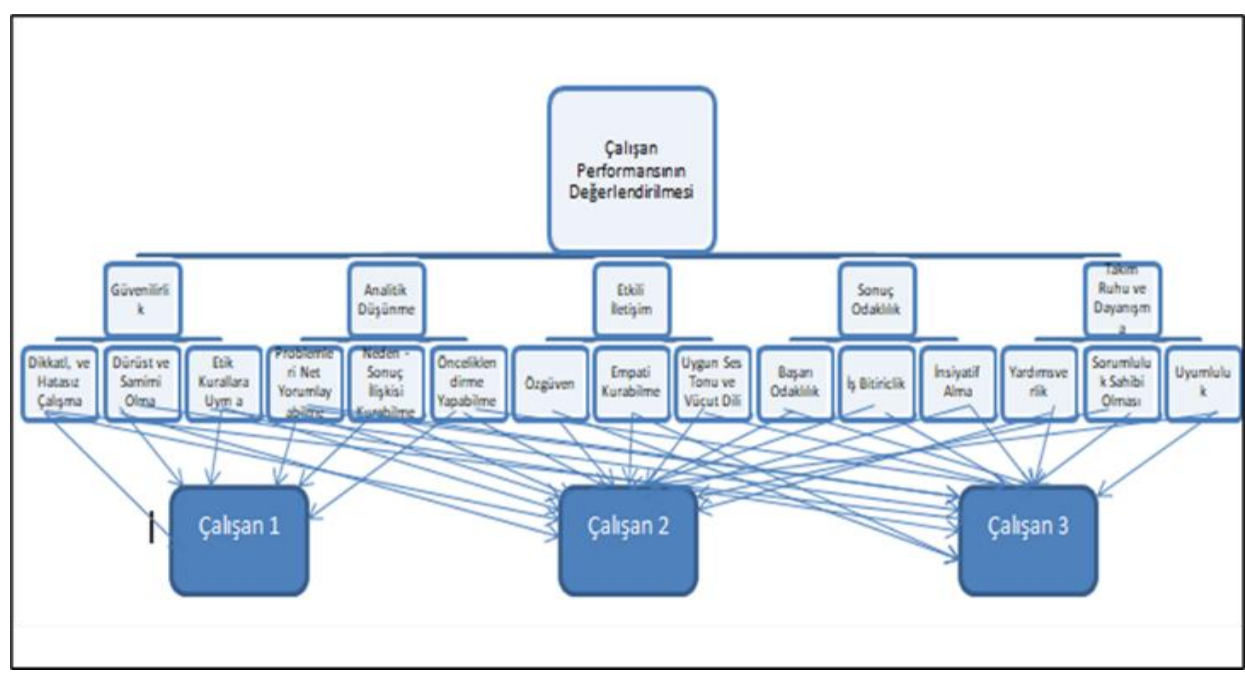

Şekil 2. Problemin hiyerarşik yapısı

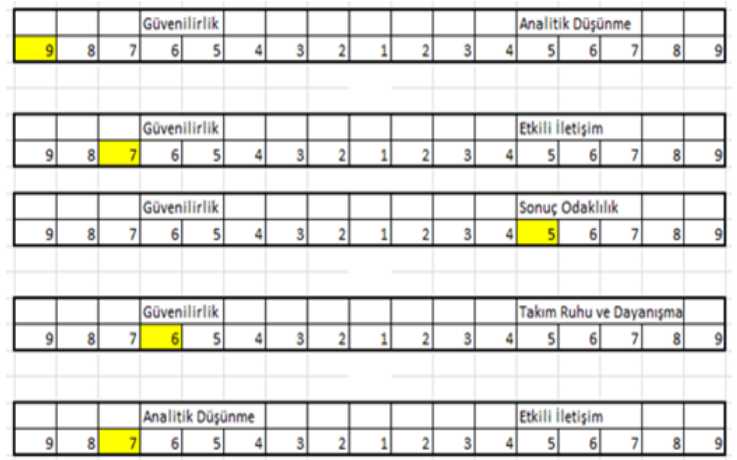

Şekil 3. Ana kriterlerin ikili kıyaslamasının yapıldığg anket örneği

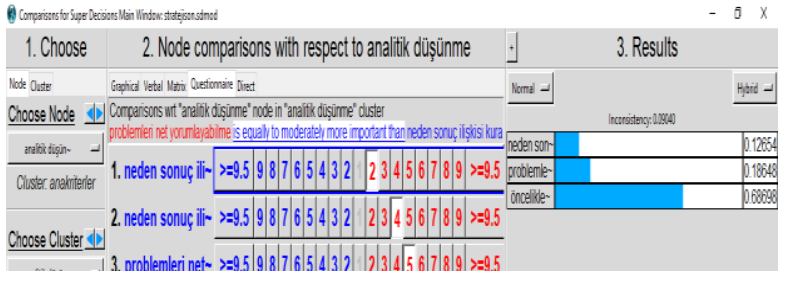

Şekil 4. Programda yer alan ikili karşılaştırma örneği

Tablo 5. Strateji İzleme birimine ait alt kriterlerin anket sonuçları

\begin{tabular}{cc}
\hline Alt Kriter Adları & Öncelik Ağıllıkları \\
\hline Neden Sonuç İlişkisi Kurabilme & 0.008436 \\
Problemleri Net Yorumlayabilme & 0.012432 \\
Önceliklendirme Yapabilme & 0.045799 \\
Empati Kurabilme & 0.046064 \\
Uygun Ses Tonu ve Vücut Dili & 0.006093 \\
Özgüven & 0.014509 \\
Dikkatli ve Hatasız Çalışabilme & 0.019005 \\
Dürüst ve Samimi Olabilme & 0.043511 \\
Etik Kurallara Uyma & 0.004151 \\
Başarı Odaklılık & 0.012267 \\
İnsiyatif Alma & 0.015455 \\
İş Bitiricilik & 0.038945 \\
Sorumluluk Sahibi Olması & 0.018646 \\
Uyumluluk & 0.04178 \\
Yardımseverlik & 0.006241 \\
\hline
\end{tabular}

Tablo 6. Strateji izleme birimi alternatiflere ait anket sonuçları

\begin{tabular}{cc}
\hline Alternatifler & Öncelik Ağırlıkları \\
\hline Çalışan1 & 0.083284 \\
Çalısan2 & 0.06846 \\
Çalışan3 & 0.181589 \\
\hline
\end{tabular}

Tablo 6'da yer alan alternatifler için yapılan değerlendirmede "Çalışan 3" (\%18.15) en iyi performansa sahip olarak çıkmıştır. Bunun sebebi "Empati kurabilme" alt kriterine oldukça fazla sahip olmasıdır. "Çalışan 2" (\%6.84) en kötü performansa sahip alternatif olarak çıkmıştır. Bunun sebebi ise "Etik kurallara uyma" kriterine az seviyede sahip olmasidir.

\subsection{Eğitim müdürlüğü sonuçları}

Eğitim Müdürlüğü birimi için kriter öncelik ağırlıklarını değerlendirdiğimizde, Tablo 7 ve 8'de yer alan sonuçlarda ana kriterler için yapılan değerlendirmelerde eşit önem derecelerine (\%6.66) sahip oldukları ortaya çıkmıştır. Alt kriterler için yapılan değerlendirmeler sonucunda "Empati kurabilme" ve "Etik kurallara uyabilme" (\% 4.178) en önemli alt kriterler olarak çıkarken, "Uygun ses tonu ve vücut dili" ve "Dürüst ve samimi olma" (\% 0.6241) alt kriterleri ise en az öneme sahip olarak çıkmışlardır.

Tablo 7. Eğitim Müdürlüğü'ne ait alt kriterlerin anket sonuçları

\begin{tabular}{cc}
\hline Ana Kriter Adları & Öncelik Ağılıkları \\
\hline Analitik Düşünme & 0.66667 \\
Etkili İletişim & 0.66667 \\
Güvenilirlik & 0.66667 \\
Sonuç Odaklılık & 0.66667 \\
Takım Ruhu ve Dayanışma & 0.66667 \\
\hline
\end{tabular}


Tablo 8. Eğitim Müdürlüğü'ne ait alt kriterlerin anket sonuçları

\begin{tabular}{cc}
\hline Alt Kriter Adları & Öncelik Ağılıkları \\
\hline Neden Sonuç İlişkisi Kurabilme & 0.017891 \\
Problemleri Net Yorumlayabilme & 0.040961 \\
Önceliklendirme Yapabilme & 0.007815 \\
Empati Kurabilme & 0.04178 \\
Uygun Ses Tonu ve Vücut Dili & 0.006241 \\
Özgüven & 0.018646 \\
Dikkatli ve Hatasız Çalışabilme & 0.018646 \\
Dürüst ve Samimi Olabilme & 0.006241 \\
Etik Kurallara Uyma & 0.04178 \\
Başarı Odaklılık & 0.02297 \\
İnsiyatif Alma & 0.007235 \\
İş Bitiricilik & 0.036462 \\
Sorumluluk Sahibi Olması & 0.040961 \\
Uyumluluk & 0.017891 \\
Yardımseverlik & 0.007815
\end{tabular}

Tablo 9. Eğitim Müdürlüğü alternatiflere ait anket sonuçları

\begin{tabular}{cc}
\hline Alternatifler & Öncelik Ağılılıkarı \\
\hline Çalı̧san1 & 0.135306 \\
Çalışan2 & 0.108482 \\
Çalışan3 & 0.089545 \\
\hline
\end{tabular}

Tablo 9'da yer alan sonuçlara bakıldığı zaman en iyi performansa sahip alternatif "Çalışan 1" (\%13.53) olup, bu duruma sebep ise "Empati kurabilme" ve "Etik kurallara uyabilme" alt kriterlerine iyi derecede sahip olmasıdır. "Çalışan 3" (\%8.954) ise en kötü performansa sahip alternatif olarak çıkmıştır. Bunun sebebi ise "Uygun ses tonu ve vücut dili" ve "Dürüst ve samimi olma" alt kriterlerine az derecede sahip olmasıdır. Eğitim Müdürlüğü için Çalışan1'in performansı en iyidir.

\section{Sonuç}

Çalışma koşullarının günümüz koşullarında yaşadığ değişikliklerle birlikte rekabetin artması, nitelikli çalışan sayısının artması gibi nedenlerden kaynaklı olarak çalışan performansının değerlendirilmesi kurumlar, işletmeler, örgütler adına büyük önem taşımaktadır. Çalışanın işinde nasıl ve ne derecede başarılı olduğunu belirleyebilmek adına işletmeler ve kurumlar çalışan performansının değerlendirilmesine ihtiyaç duyar. Performans değerlendirme, çalışanın zayıf ve yetersiz özelliklerinin belirlenmesinde, oluşabilecek problemlerin ortaya çıkarılmasında, eğitim ihtiyaçlarının ve gerekli gelişim ve motivasyon tiplerinin belirlenmesinde oldukça büyük katkıya sahiptir. Çalışan performansı değerlendirmenin geri bildirim altında olması sorunu tespit etmekle kalmaz, aynı zamanda olan problemlere çözüm getiren konumda olmasını sağlamıştır.

Çalışmamızda değerlendirdiğimiz kurumun işçi, memur ve sözleşmeli memur çalışanları için 2012 yılından beri performans değerlendirme ile ilgili araştırmalar yapmakta ve çalışan performans değerlendirme sistemi uygulamaktadır. Uygulanan bu sistemde öncelikle çalışanlarına eğitimler verilir ve verilen eğitimlerle birlikte çalışanlarını bilgilendirmiş olur. 2014 yılında yenilenen performans değerlendirme sistemi Performans Gelişim Sistemi olarak değiştirilmiştir. Bu sistemle birlikte çok yönlü değerlendirme yapabilmek adına 360 derece performans değerlendirme sistemi modeline geçilmiştir. Çalışanların bireysel, üst ve varsa astları olan aynı mertebedeki üç personel tarafından değerlendirilmesiyle birbirlerine verilen puanlar gizli tutularak sonuçlar yöneticilerle paylaşılır. Paylaşılan sonuçlar çalışanlara geri bildirim olarak gönderilir ve çalışanın performans gelişimine ve işin verimliliğine katkı sağlamak adına gerekli eğitim, motivasyonlar belirlenir.

$\mathrm{Bu}$ çalışma ile birlikte, belirtilen birimlerde çalışan performansının değerlendirilmesi adına var olan performans değerlendirme sistemi sonuçları ile elde edilen sonuçlar karşılaştırılarak, yeni bir değerlendirme yapılmıştır.

Kriterler ve alternatifler belirlenerek hiyerarşik yapı oluşmuştur. 5 ana kriter ve her bir ana kritere ait 3'er alt kriterle birlikte 15 alt kriter olmak üzere toplam 20 kriter ve 3 alternatif belirlenmiştir. Çalışan performansını değerlendirirken kriterlerin ne derece öneme sahip olduğunu ve alternatif 3 çalışanın performansının kriterler açısından değerlendirmek için iki birimde yer alan 6 kişiye yapılan anketlerden elde edilen değerler Superdecision adlı programa girilmiştir. Elde edilen bulgular sonucunda, Strateji İzleme birimi için ana kriterler eşit önem derecesine sahip olarak çıkarken, en önemli alt kriteri "empati kurabilme" olarak çıkmış ve en az önemli alt kriter ise "etik kurallara uyma" çıkmıştır. Eğitim Müdürlüğü için ise, ana kriterler eşit önem derecesine sahip olarak çıkmıştır. En önemli alt kriterler "Empati kurabilme" ve "Etik kurallara uyabilme" olarak çıkmış, en az önemli kriterler ise "Uygun ses tonu ve vücut dili" ve "Dürüst ve samimi olma" olarak çıkmıştır. Alternatifler için yapılan anket çalışması sonuçlarına bakıldığı zaman Strateji İzleme birimine göre Çalışan 3 en iyi performansa sahip olarak çıkmış, Çalışan 2 ise en kötü performansa sahip alternatif olarak çıkmıştır. Eğitim Müdürlüğü'ne göre yapılan anket çalışması sonucunda Çalışan 1 en iyi performansa sahip alternatif olup, Çalışan 3 ise en kötü performansa sahip alternatif olmuştur.

Çalışmamızda iki birimde ortak olarak belirlenen 3 çalışan için en iyi ve en kötü performans göstermesinde etkili olan kriterler aşağıda yer almaktadır:

Strateji İzleme biriminin değerlendirmesine göre en iyi performans gösteren Çalışan 3 çıkmış ve en iyi performans göstermesine sebep olan kriter ise "Empati kurabilme" alt kriteridir. Yine aynı birime göre en kötü performans gösteren Çalışan 2 olarak çıkmış ve en kötü performans göstermesine sebep olan kriter ise "Etik kurallara uyma" alt kriteridir.

Eğitim Müdürlüğü’nün yapmış olduğu değerlendirmeye göre en iyi performansa sahip olan Çalışan 1 olarak çıkmıştır ve buna sebep olan kriter "Empati kurabilme" ve "Etik kurallara uyma" alt kriterleridir. En kötü performansa sahip olan alternatif ise Çalışan 3 ve buna sebep olan kriter ise "Uygun ses tonu ve vücut dili" ve "Dürüst ve samimi olma" 
alt kriterleridir. Çıkan bu sonuçları göre kurum, bu çalışanlar için gerekli eğitim ve motivasyonları vermesi gerekecektir.

$\mathrm{Bu}$ çalışmada, çalışan performansının değerlendirilmesinde etkili faktörler ele alınmıștır. Değerlendirmeler için ÇKKV yöntemlerinden AHP tekniği ele alınmıştır. Yapılan çalışmayla birlikte, çalışanların mevcut durumlarının belirlenen kriterler bazında değerlendirilerek etkin sonuç analizleri paylaşılmıştır ve bu analizlerden yola çıkarak çalışma verimliliği ve performans yükseltilmesinde faydalı olacağı düşünülmektedir. Çalışma ile birlikte, farklı kurum ve birimlerdeki çalışan performanslarının değerlendirilmesinde yol göstermesi umulmaktadır.

\section{Çıkar çatışması}

Yazarlar çıkar çatışması olmadığını beyan etmektedir.

Benzerlik oranı (iThenticate): \%14

\section{Kaynaklar}

[1] K. Yaralığlu, Performans değerlendirmede analitik hiyerarşi prosesi. Dokuz Eylül Üniversitesi İktisadi İdari Bilimler Fakültesi Dergisi, 16 (1), 129-142, 2001. https://dergipark.org.tr/tr/pub /deuiibfd/ issue/22766/B 243002.

[2] E. Eraslan ve O. Algün, İdeal performans değerlendirme formu tasarımında analitik hiyerarşi yöntemi yaklaşımı. Gazi Üniversitesi MühendislikMimarlık Fakültesi Dergisi, Ankara, 20 (1), 95-106, 2005. https://dergipark.org.tr/tr/pub/gazimmfd/iss ue/ 66 63/88882.

[3] S. Güney, S. C. Uludağ ve İ. S. Mert, Performans değerlendirmede analitik hiyerarşi prosesi. Anadolu Bil Meslek Yüksekokulu Dergisi, 18, 53-68, 2010. https://dergipark.org.tr/tr/pub/abmyoder/issue/46456/5 83584.

[4] G. Akkaya, Analitik hiyerarşi yöntemi ile personel seçimi ve bir uygulama. Verimlilik Dergisi, 4, 0-0, 2010.https://dergipark.org.tr/tr/pub/verimlilik/issue/30 542/330516.

[5] N. Uçkun ve G. Girginer, Türkiye'deki kamu ve özel bankaların performanslarının gri ilişki analizi ile incelenmesi. Akdeniz İİBF Dergisi, 11 (21), 46-66, 2011. https://dergipark.org.tr/tr/pub/auiibfd /iss ue/ $32324 / 359212$.

[6] İ. Kır ve M. O. Çetik, 360 derece performans değerlendirme sisteminde AHP kullanımı ve bir uygulama. Ç.Ü. Fen ve Mühendislik Bilimleri Dergisi 27(2), 153-162, 2012. https://docplayer. biz.tr/ 10043 448-360-derece-performansdegerlendirme-yontemini n-ahp-analizi-ile-karsilastirilmasi-ve-bir-uygulamaozet.html.

[7] A. Çelikdin ve H. Karadal, Balanced scorecard ile analitik hiyerarşik proses yönteminin kullanılabilirliği üzerine bir uygulama. Sosyal ve Beşerî Bilimler Dergisi 5 (2), 142-151, 2013. https:// dergipark.org .tr/tr/pub/sobiadsbd/issue/22122/237597.

[8] D. N. Özgür ve S. Gencan, VZA/AHP bütünleşik yöntemi ile performans ölçümü: Ankara'daki kamu hastaneleri üzerine bir uygulama. Gazi Universitesi
Iktisadi ve Idari Bilimler Fakultesi Dergisi 16 (2), 88112, 2014. https://dergipark.org.tr/en/pub/ gazi uii bfd /issue/28310/300847.

[9] M. Karaatl1, N. Ömürbek, ve G. Köse, Analitik hiyerarşi süreci temelli topsis ve vikor yöntemleri ile futbolcu performanslarının değerlendirilmesi. Dokuz Eylül Üniversitesi İktisadi ve İdari Bilimler Fakültesi Dergisi 29 (1), 25-61, 2014.https:// dergi park.org.tr/tr /pub/deuiibfd/issue/22719/242477.

[10] B. Özyörük, Performans ölçümünde balanced scorecard ve analitik hiyerarşi prosesi entegrasyonu. TÜBAV Bilim Dergisi 7 (1), 7-28, 2014. https:// dergi park.org.tr/en/pub/tubav/issue/21534/230991.

[11] M. Karaatlı, Çok kriterli karar verme teknikleri ile performans değerlendirmesine ilişkin bir uygulama. Sosyal Bilimler Araştırma Dergisi 4 (2), 176-186, 2015.https://dergipark.org.tr/tr/pub/ssrj/issue/22479/2 40438.

[12] A. S. Uludağ ve H. Doğan, Çok kriterli karar verme yöntemlerinin karşılaştırılmasına odaklı bir hizmet kalitesi uygulaması. Çankırı Karatekin Üniversitesi İktisadi ve İdari Bilimler Fakültesi Dergisi 6 (2), 17-47, 2016. https://dergipark.org tr/tr/pub/ckuiibfd/ issu e/32908/365616.

[13] E. Çalışkan ve T. Eren, Bankaların performanslarının çok kriterli karar verme yöntemiyle değerlendirilmesi. Ordu Üniversitesi Bilim ve Teknoloji Dergisi 6 (2), 85107, 2016. https://dergipark.org.tr/tr/pub/ordubtd /issue /27365/287965.

[14] Y. Aydın ve T. Eren, Savunma sanayiinde stratejik ürün için çok kriterli karar verme yöntemleri ile tedarikçi seçimi. Ömer Halisdemir Üniversitesi Mühendislik Bilimleri Dergisi 7 (1), 129-148, 2018. https://doi.org/10.28948/ngumuh.386379.

[15] M. G. Gümüş, M. Ö. Balta ve S. S. Durduran, Coğrafi bilgi sistemlerine dayalı çok kriterli karar verme teknikleri ile alışveriş merkezi kuruluş yeri seçimi: Niğde örneği. Ömer Halisdemir Üniversitesi Mühendislik Bilimleri Dergisi 8 (1), 134-146, 2019. https://doi.org/ 10.28948 /ngumuh. 495245.

[16] A. O. Kuşakcı, B. Ayvaz, F. Öztürk ve F. Sofu, Bulanık multimoora ile personel seçimi: havacılık sektöründe bir uygulama. Ömer Halisdemir Üniversitesi Mühendislik Bilimleri Dergisi 8 (1), 96-110, 2019. https://doi.org/10.28948/ngumuh. 516835.

[17] A. Öner ve F. Ülengin, Silah seçiminde Ahp yaklaşımı. Kara Harp Okulu, I. Sistem Mühendisliği ve Savunma Uygulamaları Sempozyumu, Bildiriler-II, sayfa 11091122, Türkiye, 1995.

[18] M. Deveci, F. Canıtez and N. Ç. Demirel, Setting the optimal transit fare in public transportation by using analytical hierarchy process (AHP): The case of ETT. ICENS International Conference on Engineering and Natural Science, Sarajevo, Bosna-Hersek, 24 Mayıs 2016.

[19] M. Timor, Analitik Hiyerarşi Prosesi, Türkmen Kitabevi, İstanbul, 2011 
[20] T. L. Saaty, Models, Methods, Concepts \& Applications of the Analytic Hierarch,: Springer, New York, 2001

[21] T. L. Saaty, Decision Making for Leaders, Lifetime Learning Publications, CA, 1982

[22] Ö. A. Kaynarca and İ. Ekmekçi, Service quality measurement model in urban public transportation: The case of Iett. Journal of International Trade, Logistics and Law 3 (1), 1-10, 2017. http://hdl.Handl e.net/1146 $7 / 2871$.
[23] E. Kaya, Toplam kalite yönetimi çerçevesinde performans değerlendirmesi için bulanık bir model önerisi. Yüksek Lisans Tezi, Yıldız Teknik Üniversitesi, İstanbul, Türkiye, 2016. http:// www .idealonline.com.tr/IdealOnline/makale/servicequality -measurementmodel-in-urbanpublic-transportation-the -case-of-iett/51023. 